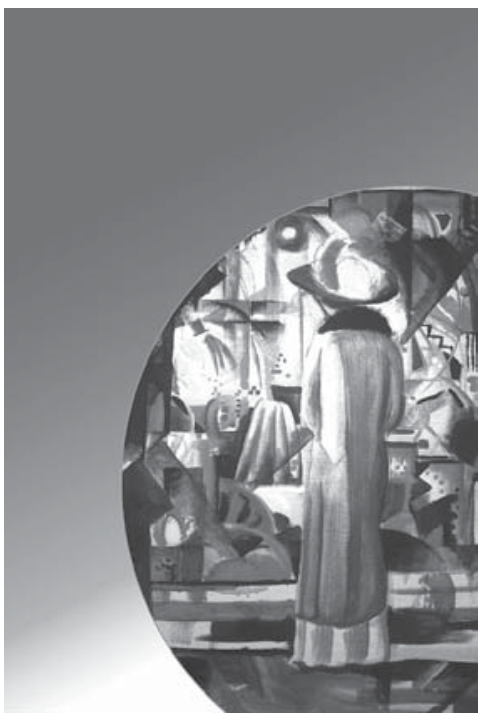




\title{
ESTUDOS DE CURRÍCULO: NOVIDADE NO FRONT*
}

\author{
Alfredo Veiga-Neto
}

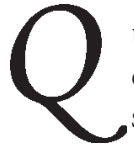

uando parecia que o mercado editorial brasileiro já contava com demasiados títulos no campo dos estudos de currículo, eis que surge uma bela novidade no front.

Organizado por dois nomes muito conhecidos no nosso cenário educacional - a professora Regina Leite Garcia e o professor Antonio Flavio Barbosa Moreira -, Currículo na contemporaneidade: incertezas e desafios, editado pela Cortez Editora, de São Paulo, é uma coletânea de dez excelentes textos, escritos por renomados especialistas estrangeiros. Nomes "da pesada", como Gimeno Sacristán, Nicholas Burbules, William Pinar, Beatriz Sarlo, James Ladwig, Luiza Cortesão e Stephen Stoer e alguns outros menos conhecidos entre nós - mas nem por isso menos interessantes -, discutem justamente aquilo que o título do livro promete: incertezas e desafios contemporâneos no campo dos estudos de currículo. Tais incertezas e desafios vão das questôes da diferença e do progressivismo à cooperação entre a escola e a universidade, da possibilidade de uma pedagogia mundial ao ensino na era da informação, do Estadonação após o globalismo à gestão da diversidade na sala de aula.

O carro-chefe desses textos é o longo e instigante diálogo travado entre a organizadora e o organizador do livro, e que funciona quase como um prefácio à obra. Por si mesmo, essas mais de 30 páginas iniciais já valem o livro. Numa linguagem direta, despretensiosa, simples mas não simplória, Regina e Antonio Flavio "começam uma conversa sobre currículo" que serve não apenas para introduzir os textos que lhe seguem como, principalmente, para exporem suas próprias convicções e ricas ex-

* Resenha do livro Currículo na contemporaneidade: incertezas e desafios, organizado por Regina Leite Garcia e Antonio Flavio Barbosa Moreira (São Paulo: Cortez, 2003).

** Doutor em Educação, professor do Programa de Pós-Graduação em Educação da Universidade Luterana do Brasil (ULBRA) e professor-convidado do Programa de Pós-Graduação em Educação da Universidade Federal do Rio Grande do Sul (UfRs).E-mail: alfredoveiganeto@uol.com.br 
periências nesse atualmente controvertido campo da educação. Ao escolherem a forma do diálogo - aliás, uma forma tão presente na tradição filosófica antiga e medieval e nas práticas medievais, renascentistas e humanistas do ensinar -, ela e ele parecem ter acertado em cheio: o texto flui fácil e, para quem os conhece, até mesmo parece que estão falando ao nosso lado. Ambos vão passando de um foco para outro sem que se sinta o passeio que estão fazendo pelos temas e problemas de que tratam os outros textos do livro. Com isso, eles parecem antecipar o que o livro vai desenvolver mais adiante. De um lado, ela: uma Regina sempre aguda e vibrante, às vezes iconoclasta. De outro lado, ele: um Antonio Flavio sempre metódico e explicativo, às vezes provocador.

Depois das alfinetadas naqueles que fazem um uso não engajado, não militante e quase asséptico do pensamento de Foucault no campo da educação - uma alfinetada que, a meu ver, é procedente em muitos casos -, a conversa segue em torno da questão demarcatória do campo do currículo. Afinal, dizem eles, se "tudo é currículo" - pois não se fala em currículo do cinema, dos jornais, da televisão, dos shopping centers, das práticas religiosas etc.? -, então a palavra se esvazia de significado e não serve para mais quase nada... É por aí que Antonio Flavio defende que "o conhecimento escolar esteja no centro das discussões sobre currículo". Concordando com ele, Regina declara seu compromisso radical com a escola. Essa questão de saber até onde se pode levar o conceito de currículo sem "enfraquecê-lo" demais é hoje uma questão bastante complica$\mathrm{da}$, tanto em termos da epistemologia e da política quanto em termos da sociologia do conhecimento e dos estudos culturais.

É claro que nenhum dos dois assume a postura de guardiães do templo, defensores de algum suposto espaço epistemológico que deveria ser ocupado pelo "verdadeiro" conceito de currículo. Mas, de fato, não é possível concordar com um vale-tudo conceitual. Como adverte Antonio Flavio, "ampliar a palavra para significar todo e qualquer espaço em que ocorra a educação acaba com a especificidade que caracteriza a escola". Com isso, ele assume a centralidade do currículo como definidor das práticas educativas que se dão nesse espaço inventado que é a escola moderna; e, em conseqüência, assume que o currículo seja o próprio demarcador daquilo que se chama escola. Mais adiante, Antonio Flavio completa: "De fato, eu não aceito que se diga que 'tudo é currículo'. Porque aí eu fico sem saber o que é currículo, eu não sei onde agir”. Nada disso é simples; penso que já é hora de conhecermos melhor os desloca- 
mentos discursivos que estão se operando nesse campo, em nosso país. Com tudo isso, já se vê que estamos às voltas com problemas que são de ordem principalmente epistemológica, mas que têm, como não poderia deixar de ser, fortes implicações políticas e sociais.

A conversa segue com comentários sobre a necessária distinção a ser feita entre qualidade social e qualidade total, no campo da educação escolarizada. Com isso, ambos (felizmente...) se afastam daqueles que exorcizam a busca da qualidade em qualquer atividade social, simplesmente porque a palavra qualidade se tornou amaldiçoada em decorrência das posturas neoliberais que a celebram como a "salvação da lavoura" no mundo do capitalismo avançado. Esse afastamento confirma aquilo que nós - que os conhecemos há tanto tempo - já sabíamos: nenhum dos dois adere ao criticismo fácil e panfletário que não é raro nos meios pedagógicos...

Em seguida, Regina e Antonio Flavio passam à interessante discussão sobre as vantagens de uma prática curricular que contemple diferentes visões de mundo, diferentes paradigmas, em cada campo do conhecimento. Se, para ele, isso parece tão mais simples no caso do ensino da história - a história vista de baixo, a história dos vencedores, a história dos vencidos etc. -, Regina habilmente mostra que também na física é possível e desejável um currículo multiparadigmático. É claro que isso pode ser estendido para qualquer outro campo, para qualquer disciplina.

Após discutirem outras questōes interessantes, ambos passam a comentar as relações entre a vida que flui na escola e as ações e os controles das Secretarias de Educação, comunidades e outras instâncias governamentais.

Já no final da conversa, Regina é categórica: "Resolvemos fazer este livro para mostrar que, em um mundo globalizado, a escola, afinal de contas, ainda é uma questão estratégica". A isso, acrescenta Antonio Flavio: "Trazer esses estudos de outros autores, de outros países, reflete, de nossa parte, a intenção de estimular o professor a refletir sobre o que faz e a melhorar o que faz".

Com esses propósitos, podemos nos lançar na leitura desses "outros autores" - da América Latina, da Europa, da América do Norte, da África e da Austrália - e descobriremos que, de fato, todos eles têm muito a nos dizer, a nos propor, a nos desafiar.

Mas como nem tudo pode ser irreparável, aqui vai um pequeno comentário sobre uma falta. Não que tal falta seja relevante ou tire o bri- 
lho e a qualidade do livro. Não se trata disso, absolutamente. Trata-se de um reparo à guisa de sugestão para as edições futuras - e torço para que elas venham a acontecer... Ressente-se a falta de mais informações acerca dos autores. Além de saber onde trabalham e seus endereços - o que consta nas orelhas da capa e da contracapa -, sabermos também o que têm produzido de mais relevância seria útil para todos nós. 